\title{
Development and Validation of a HPLC-UV Method for Simultaneous Determination of Five Sulfonylurea Herbicide Residues in Groundnut Oil Followed by Matrix Solid-Phase Dispersion
}

\author{
T. Nageswara Rao, A. Ramesh, and T. Parvathamma \\ Department of Analytical Chemistry, International Institute of Biotechnology and Toxicology (IIBAT), Padappai, \\ Kancheepuram 601301, India \\ Correspondence should be addressed to T. Nageswara Rao, tentu6581@rediffmail.com
}

Received 27 March 2012; Accepted 20 May 2012

Academic Editors: T. Bolanca, N. Chaniotakis, G. Drochioiu, N. Egashira, and G. Kardas

Copyright ( $\odot 2012$ T. Nageswara Rao et al. This is an open access article distributed under the Creative Commons Attribution License, which permits unrestricted use, distribution, and reproduction in any medium, provided the original work is properly cited.

A simple, sensitive, and inexpensive method was developed using matrix solid-phase dispersion (MSPD), together with high performance liquid chromatographic method for determination of sulfonylurea herbicide residues (nicosulfuron, pyrazosulfuron ethyl, metsulfuron methyl, chlorsulfuron and azimsulfuron) in groundnut oil. The evaluated parameters included the type and amount of sorbent (silica gel, C 18 and florisil) and the nature of eluent (ethyl acetate, dichloromethane, and acetonitrile). The best results were obtained using $1.0 \mathrm{~g}$ of groundnut oil sample, $1.0 \mathrm{~g}$ of C 18 as sorbent, and $20 \mathrm{~mL}$ of ethyl acetate-dichloromethane $(1: 1,(\mathrm{v} / \mathrm{v}))$. The method was validated using groundnut oil samples spiked with sulfonylurea herbicides at different concentration levels $(0.05$ and $0.5 \mu \mathrm{g} / \mathrm{mL}$ ). Average recoveries (using each concentration six replicates) ranged 90-97\%, with relative standard deviations less than $3 \%$, the concentration of calibration solutions was in the range $0.01-2.0 \mu \mathrm{g} / \mathrm{mL}$ and limits of detection (LOD) as well as limits of quantification (LOQ) were $0.01 \mu \mathrm{g} / \mathrm{mL}$ and $0.05 \mu \mathrm{g} / \mathrm{mL}$, respectively.

\section{Introduction}

Sulfonylureas are a family of environmentally compatible herbicides that were discovered by crop protection in 1975 and first commercialized for wheat and barley crops in 1982. They have now been developed and commercialized worldwide in all major agronomic crops and for many specialty uses.

Sulfonylurea herbicide represents a major advance global crop protection technology and has revolutionized weed control by introducing a unique mode of action. Specifically, these compounds interfere with a key enzyme required for weed cell growth-acetolactate syntheses. Furthermore sulfonylureas are compatible with the global trend toward postemergence weed control and integrated pest management $[1,2]$.
Various methods have been described for the determination of these sulfonylurea [3-5] herbicides, using solid-phase extraction (SPE), solid-phase microextraction (SPME), supercritical fluid extraction (SFE), and matrix solid-phase dispersion (MSPD). However, none of the published researches to date have reported the simultaneous analysis of chemical classes such as nicosulfuron, pyrazosulfuron ethyl, metsulfuron methyl, chlorsulfuron, and azimsulfuron in groundnut oil.

The matrix solid-phase dispersion (MSPD) technique was developed by Barker in 1989. It has advantages over conventional techniques because it employs small amounts of sample and solvent, and the extraction procedure consists of only a few experimental steps. MSPD evolved from the solid-phase extraction (SPE) technique, modified for application to solid and semisolid matrices. The MSPD 
procedure is based on the use of a sorbent $[6,7]$, which acts as an abrasive in order to produce a modified "opening" of the solid matrix, facilitating the extraction process when using a suitable solvent for eluting the analytes. The use of MSPD for sulfonylurea herbicides recovery depends on the solubility of the sulfonylurea herbicides in the eluting solvent, as well as the interactions between the matrix components, sorbent, and eluent [8].

Due to the lack of literature reports concerning the use of MSPD as an extraction technique for Sulfonylurea herbicides belonging to different chemical classes from plants, this paper presents an MSPD method for determination of residue of Sulfonylurea herbicides in groundnut oil. So, the present research considered five different chemical classes, namely, nicosulfuron, pyrazosulfuron ethyl, metsulfuron methyl, chlorsulfuron, and azimsulfuron which are analyzed by high-performance liquid chromatography with ultraviolet detector (HPLC-UV).

\section{Experimental}

2.1. Standards, Reagents, and Samples. Certificated analytical standards of nicosulfuron $(99.1 \%)$, pyrazosulfuron ethyl $(99.5 \%)$, metsulfuron methyl $(98.6 \%)$ chlorsulfuron (99.2\%), and azimsulfuron (99.7\%) were obtained from International Institute of Biotechnology and Toxicology (IIBAT). Acetonitrile was purchased from Rankem, New Delhi, analytical grade solvents, dichloromethane and ethyl acetate, were supplied from Merck Limited, Mumbai, C18bonded silica $(50 \mu \mathrm{m})$ from Phenomenex (Torrance, CA, USA), Florisil (60-100 mesh) from Fluka Chemie GmbH $\mathrm{CH}-9471$ Buchs, AR grade sodium sulphate from Merck Limited, Mumbai, and groundnut oil was purchased from local market. They were brought to the laboratory and stored in plastic bag under refrigerator condition until they were processed in the laboratory.

2.1.1. Standard Stock Solutions. The sulfonylurea herbicide standard stock solutions were individually prepared in acetonitrile at a concentration level of $100 \mu \mathrm{g} / \mathrm{mL}$ and stored in a freezer at $-18^{\circ} \mathrm{C}$. The stock standard solutions were used for up to 3 months. Suitable concentrations of working standards were prepared from the stock solutions by dilution using acetonitrile, immediately prior to sample preparation.

2.1.2. Sample Preparation. Representative $1.0 \mathrm{~g}$ portions of groundnut oil fortified with $100 \mu \mathrm{L}$ of working standard solution. The mixture was then gently blended in the mortar for $30 \mathrm{~min}$, to assess the homogeneity of the sample. The sample was allowed to stand at room temperature for one hour until analysis.

2.1.3. Extraction Procedure. $1.0 \mathrm{~g}$ of groundnut oil sample was weighed out and homogenized with $1.0 \mathrm{~g}$ of $\mathrm{C}_{18}$-bonded silica for $5 \mathrm{~min}$. The homogenized sample was transferred to an MSPD column consisting of a $20 \mathrm{~mL}$ capacity polyethylene syringe containing $1.0 \mathrm{~g}$ florisil and $1.0 \mathrm{~g}$ of anhydrous sodium sulfate. The elution was performed under vacuum

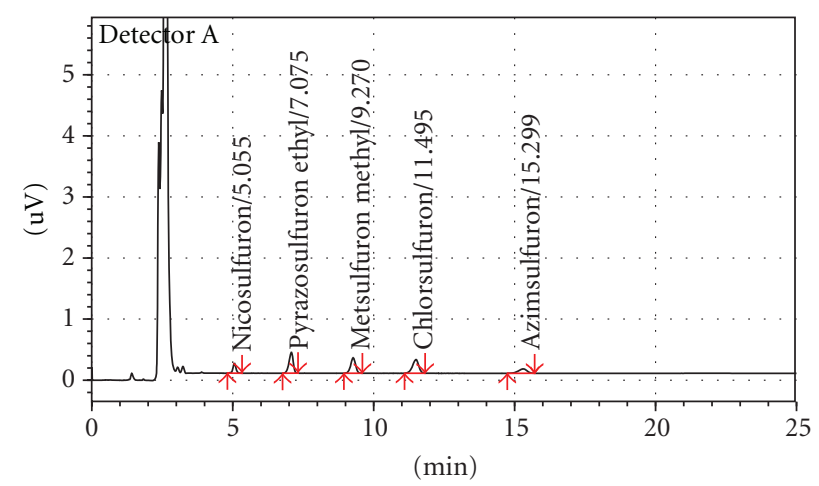

FIgURE 1: Representative chromatogram at fortification level of $0.05 \mu \mathrm{g} / \mathrm{mL}$.

with $20 \mathrm{~mL}$ of ethyl acetate-dichloromethane $(1: 1)$. The eluent was collected into a $50 \mathrm{~mL}$ tube and evaporated the sample to $5 \mathrm{~mL}$ under gentle stream of nitrogen, with the water bath temperature set at $40-45^{\circ} \mathrm{C}$.

2.1.4. Chromatographic Separation Parameters. The HPLCUV system used, consisted of Shimadzu high performance liquid chromatography with LC-20AT pump and SPD$20 \mathrm{~A}$ interfaced with LC solution software, equipped with a reversed phase C8 analytical column of $150 \mathrm{~mm} \times 4.6 \mathrm{~mm}$ and particle size $3.5 \mu \mathrm{m}$ (Zorbax SB-C8) column temperature was maintained at $40^{\circ} \mathrm{C}$. The injected sample volume was $20 \mu \mathrm{L}$. Mobile phases A and B were acetonitrile and $0.1 \%$ formic acid $(70: 30(\mathrm{v} / \mathrm{v}))$. The flow-rate used was kept at $1.2 \mathrm{~mL} / \mathrm{min}$. The detector wavelength was $225 \mathrm{~nm}$. The external standard method was used for this analysis.

2.1.5. Method Validation. Method validation ensures analysis credibility. In this study, the parameters accuracy, precision, linearity, and limits of detection (LOD) and quantification (LOQ) were considered. The accuracy of the method was determined by recovery tests, using samples spiked at concentration levels of 0.05 and $0.5 \mathrm{mg} / \mathrm{kg}$. Linearity was determined by different known concentrations $(0.01,0.05$, $0.1,0.5,1.0$, and $2.0 \mu \mathrm{g} / \mathrm{mL}$ ) which were prepared by diluting the stock solution. The limit of detection (LOD, $\mu \mathrm{g} / \mathrm{mL}$ ) was determined as the lowest concentration giving a response of 3 times the baseline noise defined from the analysis of control (untreated) sample. The limit of quantification (LOQ, $\mu \mathrm{g} / \mathrm{mL}$ ) was determined as the lowest concentration of a given herbicide giving a response of 10 times the baseline noise.

\section{Results and Discussion}

3.1. Specificity. Specificity was confirmed by injecting the groundnut oil control. There were no matrix peaks in the chromatograms to interfere with the analysis of herbicide residues shown in Figure 1. Furthermore, the retention times of nicosulfuron, pyrazosulfuron ethyl, metsulfuron methyl, 


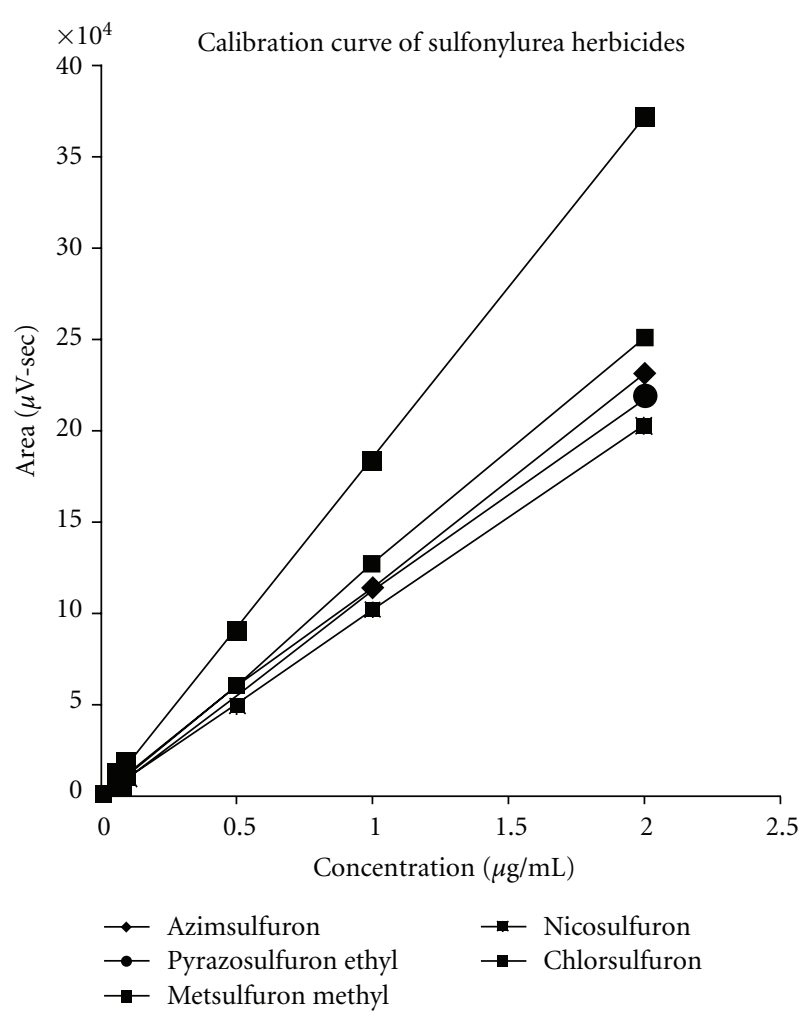

FIGURE 2: Representative calibration curve of sulfonylurea herbicides.

chlorsulfuron and azimsulfuron were constant at $5.0 \pm 0.2$, $7.0 \pm 0.2,9.2 \pm 0.2,11.5 \pm 0.2$, and $15.3 \pm 0.2 \mathrm{~min}$.

3.2. Linearity. Different known concentrations of sulfonylurea herbicides $(0.01,0.05,0.1,0.5,1.0,2.0 \mu \mathrm{g} / \mathrm{mL})$ were prepared in acetonitrile by diluting the stock solution. The standard solutions were injected and recorded the peak areas. A calibration curve has been plotted of concentration of the standards injected versus area observed and the linearity of method was evaluated by analyzing six solutions. The peak areas obtained from different concentrations of sulfonylurea herbicides were used to calculate linear regression equations. These were $Y=101469.4 X+65.61, Y=110014.8 X+73.47$, $Y=115609.9 X+49.91, Y=125626.26 X+4.98$, and $185227.9+33.48$ with correlation coefficients of $0.999,1.000$, $0.999,0.999$, and 0.999 for nicosulfuron, pyrazosulfuron ethyl, metsulfuron methyl, chlorsulfuron, and azimsulfuron, respectively. A calibration curve was show in Figure 2.

3.3. Accuracy and Precision. Recovery studies were carried out at 0.05 and $0.5 \mu \mathrm{g} / \mathrm{mL}$ fortification levels for nicosulfuron, pyrazosulfuron ethyl, metsulfuron methyl, chlorsulfuron, and azimsulfuron in groundnut oil. The recovery data and relative standard deviation values obtained by this method are summarized in Table 1.
These numbers were calculated from five (6) replicate analyses of given sample (nicosulfuron, pyrazosulfuron ethyl, metsulfuron methyl, chlorsulfuron, and azimsulfuron) made by a single analyst on one day. The repeatability of method was satisfactory (RSDs <3\%).

3.4. Detection and Quantification Limits. The limit of quantification was determined to be $0.05 \mu \mathrm{g} / \mathrm{mL}$. The quantitation limit was defined as the lowest fortification level evaluated at which acceptable average recoveries (90-97\%, RSD <3\%) were achieved. This quantitation limit also reflects the fortification level at which an analyte peak is consistently generated at approximately 10 times the baseline noise in the chromatogram. The limit of detection was determined to be $0.01 \mu \mathrm{g} / \mathrm{mL}$ at a level of approximately three times the back ground of control injection around the retention time of the peak of interest.

3.5. Storage Stability. A storage stability study was conducted at $-20 \pm 1^{\circ} \mathrm{C}$ with groundnut oil samples spiked with $0.1 \mu \mathrm{g} / \mathrm{mL}$ of nicosulfuron, pyrazosulfuron ethyl, metsulfuron methyl, chlorsulfuron, and azimsulfuron Samples and stored for a period of 30 days at this temperature. Nicosulfuron, pyrazosulfuron ethyl, metsulfuron methyl, chlorsulfuron and azimsulfuron contents were analysed before storing and at the end of storage period. The percentage dissipation observed for the above storage period was only $2 \%$ for nicosulfuron, pyrazosulfuron ethyl, metsulfuron methyl, chlorsulfuron, and azimsulfuron showing no significant loss of residues on storage. The results are presented in Table 2.

\section{Conclusions}

This paper describes for the first time a fast, simple, and sensitive analytical method based on MSPD with HPLC-UV developed and validated for the simultaneous determination of five sulfonylurea herbicides residues in groundnut oil.

The MSPD extraction procedure of the described method is very simple and requires no sample preparation or pretreatment, providing adequate cleanup of the matrix. Whole groundnut oil extracts are very clean, with no interfering peaks at the retention time of the target compounds, indicating good selectivity of the proposed method.

The mobile phase acetonitrile and $0.1 \%$ formic acid yield good separation and resolution and the analysis time required for the chromatographic determination of the five Sulfonylurea herbicides are very short (around $25 \mathrm{~min}$ for a chromatographic run).

Satisfactory validation parameters such as linearity, recovery, precision, and very low limits were obtained according to the EU guidelines. For all of the sulfonylurea herbicides the sensitivity of the method was good enough to ensure reliable determination levels lower than the respective MRLs. Therefore, the proposed analytical procedure could satisfactorily be useful for regular monitoring of sulfonylurea herbicides residues on a large number of oil samples. 
TABLE 1: Recoveries of the sulfonylurea herbicides from fortified groundnut oil control sample $(n=6)$.

\begin{tabular}{|c|c|c|c|c|c|c|}
\hline \multirow{2}{*}{$\begin{array}{l}\text { Fortification concentration } \\
\text { in } \mu \mathrm{g} / \mathrm{mL}\end{array}$} & \multirow{2}{*}{ Replication } & \multicolumn{5}{|c|}{ Recovery (\%) } \\
\hline & & Nicosulfuron & Pyrazosulfuron ethyl & Metsulfuron methyl & Chlorsulfuron & Azimsulfuron \\
\hline \multirow{8}{*}{0.03} & $\mathrm{R} 1$ & 88 & 87 & 90 & 89 & 91 \\
\hline & $\mathrm{R} 2$ & 90 & 90 & 91 & 88 & 90 \\
\hline & R3 & 91 & 89 & 89 & 89 & 94 \\
\hline & $\mathrm{R} 4$ & 89 & 88 & 93 & 90 & 93 \\
\hline & R5 & 89 & 88 & 90 & 91 & 91 \\
\hline & R6 & 90 & 90 & 90 & 93 & 90 \\
\hline & Mean & 90 & 89 & 91 & 90 & 92 \\
\hline & RSD & 1.17 & 1.36 & 1.52 & 1.99 & 1.80 \\
\hline \multirow{8}{*}{0.3} & $\mathrm{R} 1$ & 95 & 93 & 95 & 93 & 96 \\
\hline & $\mathrm{R} 2$ & 98 & 96 & 93 & 93 & 93 \\
\hline & R3 & 96 & 94 & 96 & 94 & 92 \\
\hline & $\mathrm{R} 4$ & 95 & 94 & 92 & 92 & 95 \\
\hline & R5 & 95 & 93 & 94 & 93 & 93 \\
\hline & R6 & 93 & 93 & 92 & 95 & 92 \\
\hline & Mean & 95 & 94 & 94 & 93 & 94 \\
\hline & RSD & 1.71 & 1.25 & 1.74 & 1.11 & 1.76 \\
\hline
\end{tabular}

TABLE 2: Storage stability details $(n=6)$.

\begin{tabular}{|c|c|c|c|c|c|c|c|}
\hline \multirow{2}{*}{$\begin{array}{l}\text { Fortified concentration } \\
\text { in } \mu \mathrm{g} / \mathrm{mL}\end{array}$} & \multirow{2}{*}{$\begin{array}{l}\text { Storage period } \\
\text { in Days }\end{array}$} & \multirow[b]{2}{*}{ Replication } & \multicolumn{5}{|c|}{ Recovery in \% } \\
\hline & & & Nicosulfuron & $\begin{array}{c}\text { Pyrazosulfuron } \\
\text { ethyl }\end{array}$ & $\begin{array}{l}\text { Metsulfuron } \\
\text { methyl }\end{array}$ & Chlorsulfuron & Azimsulfuron \\
\hline \multirow{16}{*}{0.1} & \multirow{7}{*}{0} & $\mathrm{R} 1$ & 92 & 93 & 91 & 91 & 92 \\
\hline & & $\mathrm{R} 2$ & 94 & 94 & 93 & 93 & 93 \\
\hline & & R3 & 95 & 92 & 95 & 91 & 95 \\
\hline & & $\mathrm{R} 4$ & 92 & 92 & 92 & 95 & 93 \\
\hline & & R5 & 93 & 94 & 94 & 92 & 94 \\
\hline & & R6 & 92 & 92 & 91 & 92 & 92 \\
\hline & & Mean & 93 & 93 & 93 & 92 & 93 \\
\hline & \multirow{9}{*}{30} & RSD & 1.36 & 1.25 & 1.76 & 1.63 & 1.25 \\
\hline & & $\mathrm{R} 1$ & 90 & 91 & 90 & 89 & 91 \\
\hline & & $\mathrm{R} 2$ & 89 & 90 & 89 & 89 & 89 \\
\hline & & R3 & 90 & 92 & 90 & 91 & 91 \\
\hline & & $\mathrm{R} 4$ & 91 & 89 & 91 & 90 & 91 \\
\hline & & R5 & & 90 & 92 & 91 & 91 \\
\hline & & R6 & 91 & 91 & 92 & 91 & 89 \\
\hline & & Mean & 91 & 91 & 91 & 91 & 90 \\
\hline & & RSD & 1.08 & 1.05 & 1.34 & 1.14 & 1.03 \\
\hline
\end{tabular}

\section{Acknowledgment}

The authors are thankful to the management and Dr. P. Balakrishnamurthy, Director, IIBAT, for providing necessary facility to conduct the experiment.

\section{References}

[1] P. Klaffenbach, P. T. Holland, and D. R. Lauren, "Analysis of sulfonylurea herbicides by gas-liquid chromatography. 1 .
Formation of thermostable derivatives of chlorsulfuron and metsulfuron-methyl," Journal of Agricultural and Food Chemistry, vol. 41, no. 3, pp. 388-395, 1993.

[2] S. Seccia, S. Albrizio, P. Fidente, and D. Montesano, "Development and validation of a solid-phase extraction method coupled to high-performance liquid chromatography with ultraviolet-diode array detection for the determination of sulfonylurea herbicide residues in bovine milk samples," Journal of Chromatography A, vol. 1218, no. 9, pp. 1253-1259, 2011.

[3] S. Ishimitsu, A. Kaihara, K. Yoshii, Y. Tsumura, Y. Nakamura, and Y. Tonogai, "Simultaneous determination of azimsulfuron, flazasulfuron and halosulfuron-methyl in grains, seeds, 
vegetables and fruits by HPLC," Journal of Health Science, vol. 48, no. 4, pp. 335-340, 2002.

[4] K. C. Wang, S. M. Chen, J. F. Hsu, S. G. Cheng, and C. K. Lee, "Simultaneous detection and quantitation of highly watersoluble herbicides in serum using ion-pair liquid chromatography-tandem mass spectrometry," Journal of Chromatography $B$, vol. 876, no. 2, pp. 211-218, 2008.

[5] M. Rodriguez and D. B. Orescan, "Confirmation and quantitation of selected sulfonylurea, imidazolinone, and sulfonamide herbicides in surface water using electrospray LC/MS," Analytical Chemistry, vol. 70, no. 13, pp. 2710-2717, 1998.

[6] G. Dinelli, A. Vicari, and P. Catizone, "Monitoring of herbicide pollution in water by capillary electrophoresis," Journal of Chromatography A, vol. 733, no. 1-2, pp. 337-347, 1996.

[7] G. Stoev and A. Stoyanov, "Comparison of the reliability of the identification with diode array detector and mass spectrometry," Journal of Chromatography A, vol. 1150, no. 12, pp. 302-311, 2007.

[8] A. K. Sarmah and J. Sabadie, "Hydrolysis of sulfonylurea herbicides in soils and aqueous solutions: a review," Journal of Agricultural and Food Chemistry, vol. 50, no. 22, pp. 6253-6265, 2002. 


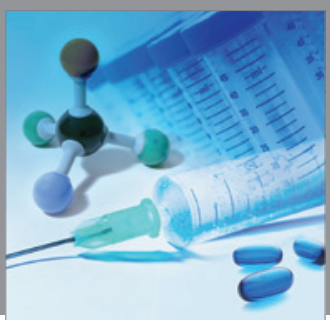

International Journal of

Medicinal Chemistry

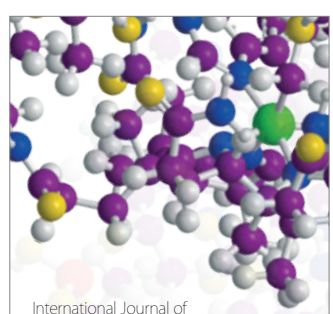

Carbohydrate Chemistry

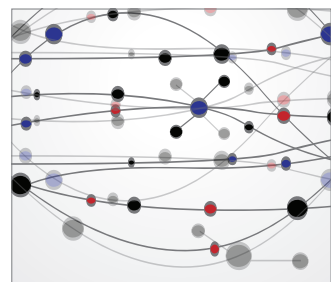

The Scientific World Journal
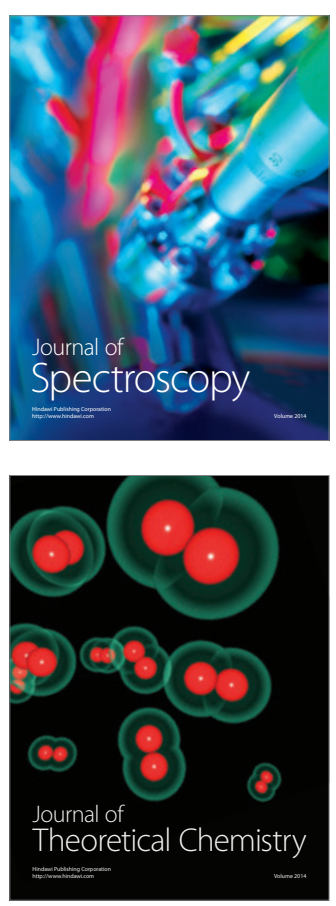
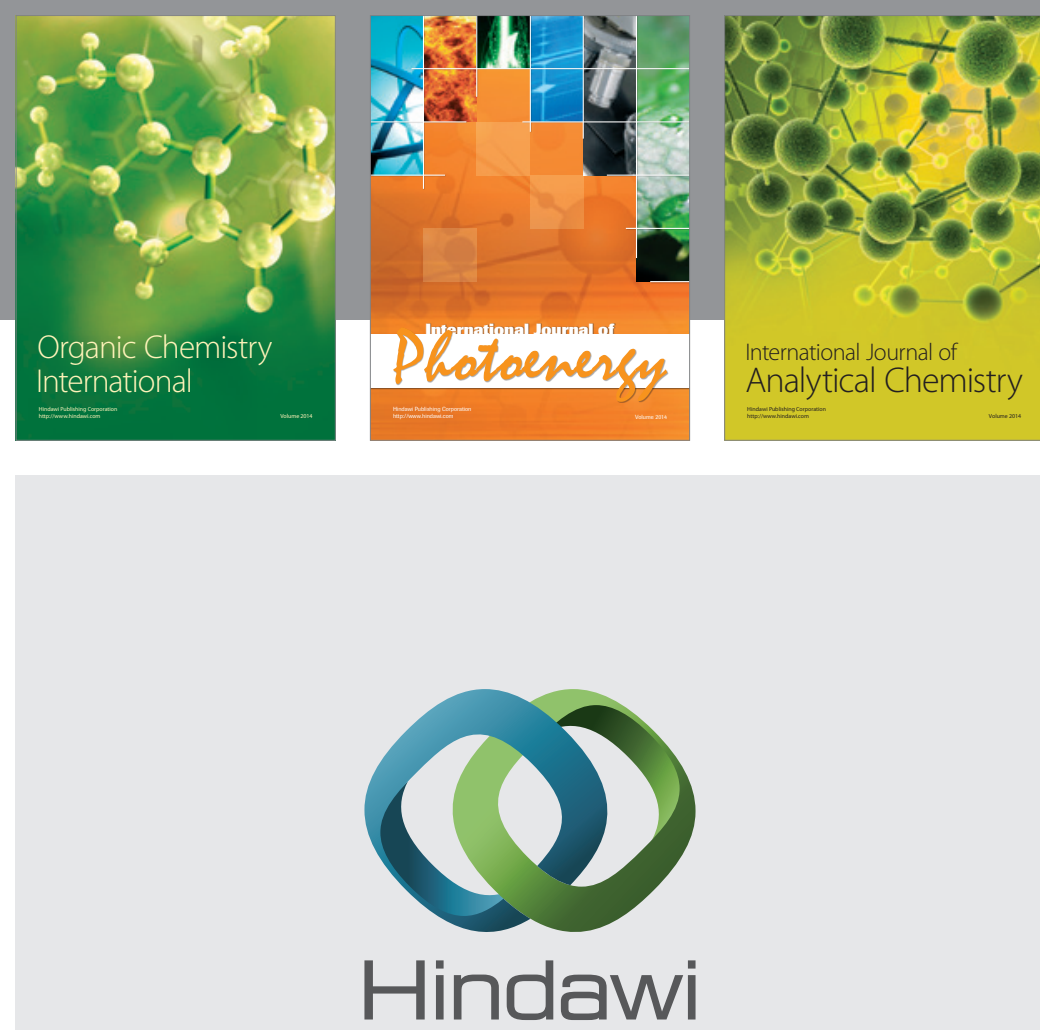

Submit your manuscripts at

http://www.hindawi.com
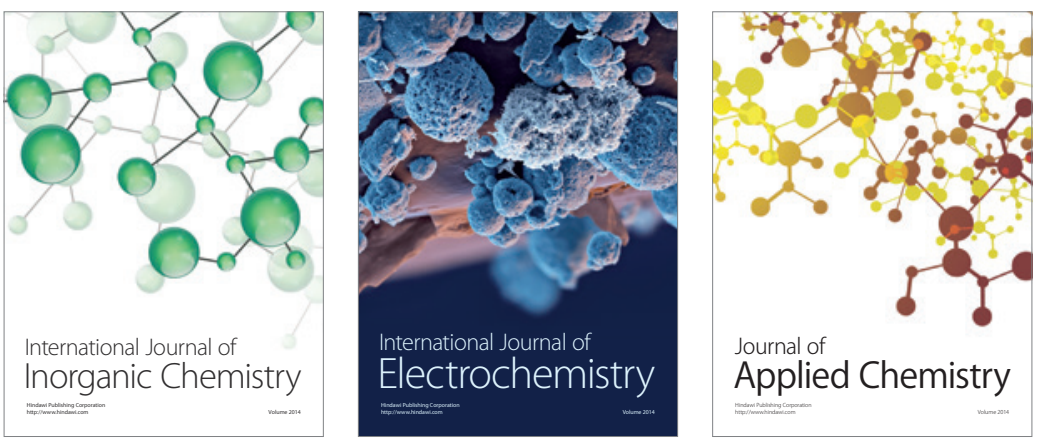

Journal of

Applied Chemistry
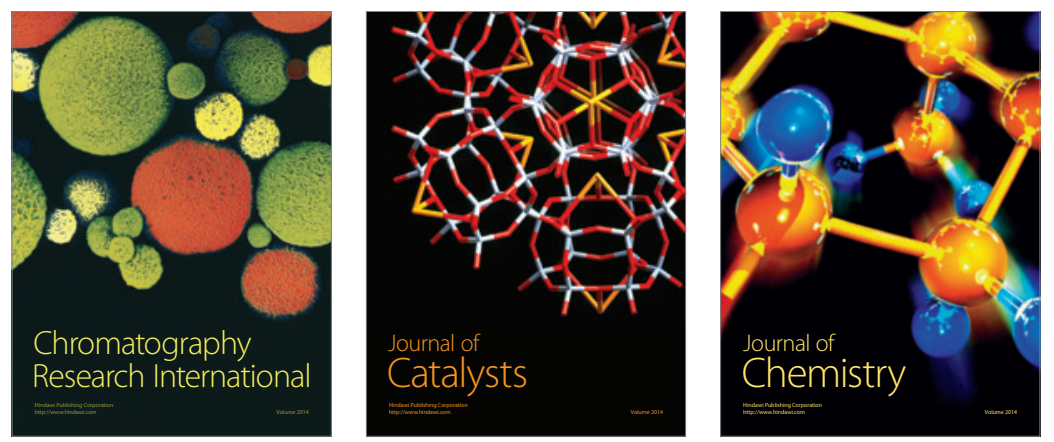
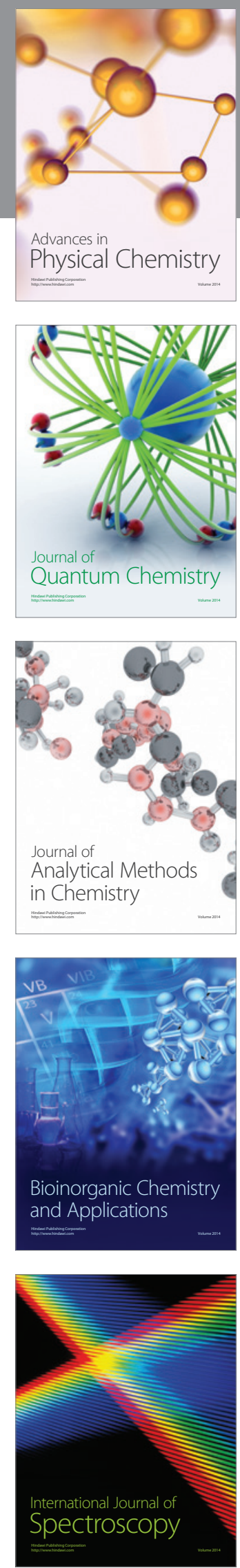